\title{
Rapid review of clinical reunification intervention to families
}

Shongile Mathebula ${ }^{1}$, Hanelie Malan ${ }^{2}$, Fatima Mmusi ${ }^{3 *}$

${ }^{1}$ Department of Social development, Gauteng, South Africa, ${ }^{2,3 *}$ School of Psychosocial Health, North-West University, South Africa.

Email: ${ }^{1}$ shongilemathebula@yahoo.com, ${ }^{2} 10603603 @$ nwu.ac.za, ${ }^{3 *}$ fatima.Mmusi@nwu.ac.za

Keywords

Family Reunification, Clinical Intervention, Attachment, Birth Parents, Meaningful Family

Engagements, Designated Social Worker.

\section{Article History}

Received on $6^{\text {th }}$ August 2021

Accepted on $17^{\text {th }}$ October 2021

Published on $27^{\text {th }}$ October 2021

\section{Cite this article}

Mathebula, S., Malan, H., \& Mmusi, F. (2021). Rapid review of clinical reunification

intervention to families. Humanities \& Social

Sciences Reviews, 9(5), 75-89.

https://doi.org/10.18510/hssr.2021.9512

\section{Copyright @Author}

Publishing License

This work is licensed under a Creative Common Attribution-Share Alike 4.0 International License (c) () (?)

\begin{abstract}
Purpose of the study: The aim of this paper is to examine literature on the clinical content of reunification interventions social workers render to families.

Methodology: A rapid review of the literature was carried out. Electronic databases, such as eBook Collection (EBSCOhost), PsycARTICLES, PsycINFO, SocINDEX with Full Text, Academic Search Premier, CINAHL with Full Text, and JSTOR Journals, were explored by making use of specific keywords. A quality appraisal was done using the CASP (2018), the AACODS checklist, and the EPHPP (2009) to appraise the quantitative studies. Eleven articles were synthesised using thematic analysis.

Main Findings: The review indicates that the exact nature of the clinical content of reunification intervention rendered to families is not clear, although empirical evidence suggests that the clinical content of reunification intervention rendered to families comprises of engagement, parental visiting and contact, parenting capacity building, and support groups. In addition, supporting birth parents with concrete resources like transportation and stable housing can be identified as an extra intervention that may support successful reunification.
\end{abstract}

Applications of this study: This study has the potential to contribute to the child welfare system by enhancing the need for programmes and policies that focus on addressing the clinical characteristics of family reunification interventions. Recommendations were made that can provide guidance and insight on the important aspects that should form part of reunification services to meet the emotional and psychological needs of the children and their birth families.

Novelty/Originality of this study: The outcome of the study has provided insight into components that are regarded to be of importance and should form part of the clinical content of reunification services rendered to families.

\section{INTRODUCTION}

The definition of a family can be viewed as the foundation of society and institution that provides its members with positive attributes, including security, a sense of belonging, sense of identity, socialisation, stability, and a secured environment (Berk, 2009; Department of Social Development, 2013; Kunz, 2013). However, contemporary family lives have become increasingly diverse and complex, and likely to leave members vulnerable to different forms of stressors. Stressors are negative attributes, such as substance abuse, domestic violence, mental illness, child abuse and neglect. These stressors may compromise the relationships within families, their ongoing existence, and put them at risk of further disintegration (Gray \& Lombard, 2008). The afore-mentioned stressors may, therefore, lead to children being found in need of care and placed in alternative care while the family of origin receives reunification services. The United Nation's guideline for the alternative care of children (2010), emphasises that the removal of children from birth families should be viewed as a measure of last resort, and whenever possible, should be temporary and for the shortest possible duration. During this period, the key role of designated social workers is to provide reunification intervention to affected families. Intervention ensures that children are returned to a stable family setting that can yield a positive influence on the cognitive, behavioural, and health outcomes of both the children and their families (Child Welfare Information Gateway, 2017).

The main objective of placing children in out-of-home care is to successfully reunite them with their immediate family members (Child Welfare Information Gateway, 2011). The goal of family reunification services is, therefore, to reduce the length of separation between children and their immediate family members, and to maximise the prospects of a successful reunion following a temporary removal (Berrick, 2008). Fernandez and Lee (2013) point out that when children remain in care for long periods, undesirable consequences are often prominent. Extended periods in care can lead to the loss of family connections, a sense of identity, and difficulties may arise while children transition out of care (Fernandez \& Lee, 2013). Furthermore, evidence suggests that children who experience multiple placements may at a 
later stage struggle to form meaningful attachments. Such children are also likely to develop long-term emotional and behavioural problems (Murphy \& Fairtlough, 2014).

Given the aforementioned, it is important to remember that reunifying children with their families is associated with certain risks. In instances where family difficulties are not adequately resolved or do not receive effective pre-and postreunification support, the reunification may be unsuccessful (Nicklin, 2019). This is more apparent in a context such as South Africa, where there is an increase in demands placed on its childcare system, perpetuated by an increased number of children entering it. In turn, the considerable number of children requiring assistance contributes to more pressure, which negatively affects its capacity to maintain effective case planning, reunification, and high standards of care.

Research by De Villiers (2008) indicates that reunification often occurs without resolving the problems that necessitated the removal in the first place. While circumstances may call for a child to be removed from the immediate risk of maltreatment, it is important to keep in mind that such an intervention, when implemented in isolation, does little to change the habitability of a home, improve parenting skills, or encourage parents to be more responsive. Research indicates that birth parents must be taught new skills that make them more effective to ensure that the child's return is successful. Although Lietz and Strength (2011) identified three key areas in which adequate measurable change should occur during the reunification process, which are identified as follows: (a) the family context, social support received, and environmental factors; (b) parental competence in providing adequately for the child's needs; and, lastly, (c) the improved quality of life and child welfare. A study conducted by Balsells et al., (2014) revealed that birth parents tend to place more emphasis on material needs, an inclination which, in turn, leads to designated social workers spending most of their (professional) time with the family addressing the physical and financial capacity of the family unit while neglecting the therapeutic or clinical aim of reunification. Furthermore, Rasaili and Titus (2007) emphasise that the reunification intervention should aim to re-establish a healthy interaction between birth parents and the child. Moreover, not only should it aspire to develop and encourage a healthy attachment and seek to readdress any emotional anxiety that the relevant parties may experience, but it should also attempt to make up for time lost during their separation. The ability to develop a supportive relationship with birth parents and engage them in therapeutic intervention has the potential to increase intervention effectiveness (Pecora \& Maluccio, 2000).

At its core, family reunification aims to adequately address the emotional and intellectual needs of families. To ensure a positive outcome, certain skills are critical to the process and include anger management, conflict resolution, parenting skills, and knowledge of child development and attachment issues. When these skills are adequately taught and applied in interventions, they will ensure that children will be safe upon their return to their birth parents' care. These abovementioned, clinical services are rendered according to different theoretical frameworks. Consequently, the reunification process requires a designated social worker to provide a therapeutic intervention that will assist both the child and the birth parent to change their feelings of attachment. Clinical interventions do not involve the provision of tangible assistance and are, instead, aimed at directly improving the emotional, psychological, and personal functioning of all parties. As these aspects improve, they may enhance the coping and interpersonal skills of both the birth parent and child. As a result, birth parents may feel empowered and develop the responsive parenting skills that are necessary for their children's development and well-being (Ryan \& Schuerman, 2004).

A family reunification intervention is made up of specific approaches which take into consideration factors such as cognitive behaviour, parental behaviour, attitude, child's developmental needs, attachment, as well as a family system approach. The latter is necessary to identify the more effective intervention for families (Child Welfare Information Gateway, 2017). The Boysville of Michigan (1991) family reunification project used a homebuilder's model that provided up to eight weeks of services; namely, three to five weeks of family preservation services and after reunification, respectively. Since the goal of this model is to achieve successful reunification, designated social workers were assigned a caseload of no more than two families and used cognitive and behavioural approaches when working with the families. This was done to ensure both soft and hard services, with workers relying on behaviourally specific goals (Bronson et al., 2008).

The behavioural, person-centred, and cognitive approaches were found to be significant when incorporated into the clinical reunification intervention. Roger's theory emphasised the attitudes and personal characteristics of the therapist and the quality of the client-therapist relationship as the prime determinant of the outcome of the therapeutic process (Corey, 2013). This means that the designated social worker's first task is to establish rapport with the client before attempting to commence the process of assistance. In addition, the cognitive-behavioural theory aims to increase people's skills and help them rearrange their thoughts to enable them to respond to challenging circumstances positively. Moreover, it is an action-oriented and educational approach, during which clients learn new and adaptive behaviours to replace old, maladaptive behaviours (Corey, 2013). The diverse approaches incorporated into this theoretical model include teaching clients mood and self-management skills to relieve anxiety, control anger, improve self-esteem, and lessen depression. Furthermore, parenting training approaches are also used to improve the clients' communication and child management skills (Bronson et al., 2008).

To maximise opportunities for children and ensure that they can be successfully reunified with their families, strong partnership, early planning, and intensive efforts with the family and other professionals are vital elements in such a process (Nicklin, 2019). A broad review of the empirical literature in child welfare suggests common characteristics of interventions that are most helpful in reunifying families when child maltreatment has been identified. 
This study was interested in examining the literature on the clinical content of reunification intervention services rendered to families, as well as making meaningful recommendations regarding the enhancement of programmes and policies aimed at addressing the clinical aspects of family reunification interventions.

\section{Research question}

What is known about the clinical content of reunification intervention rendered to families?

\section{LITERATURE REVIEW}

\section{Meaningful family engagement}

Meaningful family engagement is fundamental to successful reunification; hence the importance of the relationship between the worker and family (Child Welfare Information Gateway, 2011). Engagement entails an ongoing process that motivates the family to work with child protection and other services to plan and decide on goals (Hepworth et al., 2013). To effectively engage families in the reunification process, several activities should be utilised. These include involving immediate families during planning and decision-making, encouraging foster parents' support, as well as facilitating and encouraging visits between children in foster care with their birth parents (Child Welfare Information Gateway, 2011).

Effective case practice is about actively involving and engaging the child, birth parents, and significant others throughout the entire intervention process. Working in partnership with the family has the potential to nurture a sense of responsibility, inclusivity, and being trusted with decision-making in terms of family matters. Thus, it is important to take into consideration that families are indeed capable and do have the strength to produce solutions to their existing problems. However, they often require support and guidance to assist them during the process of implementation. While family relationships are important, a good working relationship between professionals is of equal importance to ensure that both the children and their families receive the necessary services that they require (Government of Western Australia, 2011).

For family reunification to occur successfully, birth parents need to make changes and have access to support services. Given the aforementioned information, family engagement is the key to a successful reunification; consequently, the importance of a healthy professional relationship between the worker and the child's immediate family cannot be overstated. This relationship is even more significant because, in most instances, birth parents tend to distrust the designated social workers and, therefore, may be unwilling to share information with them, or establish open and honest communication (Child Welfare Information Gateway, 2011). When families are motivated to change, they become more focused and develop the energy required to successfully navigate through the stages of change (Westfalls Associates, $\underline{2014)}$.

\section{Assessment and case planning}

Furthermore, working with birth parents who are dealing with multiple and complex problems requires an effective intervention that is planned and purposeful. It must be based on a comprehensive assessment that aims to meet each family's needs and capacities over a period (Bromfield et al., 2010). An essential part of this assessment is evaluating the birth parents' ability and motivation to change. Designated social workers require a systematic approach that uses a framework for gathering and analysing information about the children and their families (Holland, 2011). Thus, a framework for assessment for children in need is appropriate as it is underpinned by a holistic model which enables analysis and understanding of both the developmental need of the children and the capacity of the birth parents to meet those needs within their environment (Holland, 2011). This tool is closely linked to the systems theory; for instance, it values comprehensive assessment and works with individuals in their environment. Intervention becomes effective when is informed by assessment; furthermore, Nicklin (2019) indicates that Maslow's hierarchy of needs is a model that may assist in planning interventions and prioritising services.

\section{Service delivery}

Reunification requires a range of services and support from the point that a child first enters care, during care, beyond the return home. This support aims to meet the children's and their families' need for safe, timely, and sustainable reunification within the child's developmental time frames. These services include support for birth parents experiencing stress, domestic violence services, counselling, and substance abuse treatment, as well as services to address the needs of children with health and mental health, educational, developmental and/or substance abuse issues (ASPE Research Brief, 2016). Target services aimed to meet the individualised need of children and families are key to achieving family reunification and ensuring children's safety (Child Welfare Information Gateway, 2011). Fernandez and Lee (2013) highlight the importance of providing more concrete assistance to families using well-resourced reunification plans and informed early intervention and prevention services. However, there is limited research to detail what services support successful reunification (Murphy \& Fairtlough, 2014).

In an exploratory study conducted by De Villiers (2008) in South Africa, various non-governmental organisations (NGOs) that provide child protection services were studied. The findings of this study suggest that while designated social workers were providing reunification services to birth parents, they were unable to expand the content of those services due to various reasons. Furthermore, the participants reported that they often use their discretion, depending on 77 | Visit HSSR at https://mgesjournals.com/hssr/ 
the birth parent's circumstances and needs. The study also found that there was no structured programme or any other guidance in place to inform designated social workers' interventions.

Based on the aforementioned background, it can be argued that current reunification interventions, specifically in South Africa, do not adequately address the clinical needs of children and their birth parents. They ignore the most important aspects of re-negotiating the child's sense of belonging and attachment needs crucial for the child's development and total functioning. Therefore, it is important to remember that most of these children have already experienced broken or distracted attachment patterns and relationships with their primary caregivers, resulting in their removal and that the removal itself may have damaged these patterns and relationships even further. Consequently, this paper reviews past and current literature on what is known about the content of clinical intervention services provided to families during the process of reunification with their children in out-of-home care.

\section{METHODOLOGY}

The procedure of rapid review (Dobbins, 2017) was used to search, select, and extract data from literature sources that met a priori criteria. The procedure provided an allowance for knowledge to be obtained in a shorter period than required for a systematic review (Harker \& Kleijnen, 2012). The Canadian Centre on Substance Abuse (2014) describes a rapid review as a strict scientific method that aims to sum up a certain topic to provide a factual baseline for answering paramount questions in a short amount of time (Siriwardhana et al., 2014). The reviewers followed the protocol as indicated in the Rapid Review guidebook of Dobbins (2017). This protocol consists of six steps:

The first step of the procedure was to define a practice question that is relevant and focused, clearly defined, and answerable (Dobbins, 2017). A preliminary scoping search was conducted, making use of the One Search engine of the NWU library. The purpose of this was to create an outline of available literature on the research topic and to gain a better understanding of the topic being reviewed (Dundar \& Fleeman, 2014). The components of the S-Setting, P-Perspective, I-Intervention, C-Comparison and E-Evaluation (SPICE) criteria were used to determine the research question as What is known about the clinical content of reunification intervention rendered to families?

The second step aimed to identify evidence-based publications using reliable databases to address the review question (Dobbins, 2017). For this research, the issue was defined as follows: the content of clinical reunification social work interventions rendered to families. The researcher used the following databases to search for completion of the rapid review: eBook Collection (EBSCOhost), PsycARTICLES, PsycINFO, SocINDEX with Full Text, Academic Search Premier, CINAHL with Full Text, JSTOR Journals. The One Search engine of the Ferdinand Postma library of the North-West University, in Potchefstroom, South Africa provides a fast, exact, and inclusive search of 262 electronic databases. A combination of the keywords was used in the search: "Reunification services or reunification intervention", "Clinical reunification" "family services", "family reunification services" "family therapy".

The following literature sources were eligible for inclusion: Full-text journals articles, peers-reviewed data sources, noon-peer-reviewed data sources, quantitative studies, qualitative studies, mixed-methods studies, literature reviews, and grey literature such as $\mathrm{PhD}$ thesis, masters' dissertations/mini dissertations, conference proceedings and web pages. We excluded articles published in languages other than Afrikaans and English. The reviewers only included literature sources explicitly mentioning the clinical content of reunification intervention rendered to families in social work practice. The review was not time-sensitive, and therefore no time range was connected to it. The age range for this study was 0 to 18 years, as in South Africa a person between the age of 0 to 18 years of age is referred to as a child (South Africa, 2005).

During the third step, the researcher assesses the quality of the study methods used in the articles to determine if the findings are trustworthy to the relevant studies. To identify the quality of the literature, the researcher made use of the critical appraisal skills programme (CASP, 2018) for qualitative studies. The effective public health practice project (EPHPP, 2009) quality assessment tool was used to critically appraise the quantitative studies. The authors of the effective public health practice project tool have ensured that the tool meets several standards, specifically linked to the validity of the tool, the manner of evaluation, and readability. The researcher also used the AACODS (authority, accuracy, coverage, objectivity, date, significance) checklist of Tyndall (2010) that is designed to enable evaluation and critical appraisal of grey literature. Grey literature includes productions by governments, academics, businesses, and industries that are not part of the peer-reviewed publications. It can also include theses or dissertations, conference papers, and several types of reports from specialists. The researcher assessed the quality of the studies by observing how the study had been designed, conducted, and reported; this was the basis of the reliability of the studies (Boland et al. 2017).

In the fourth step, the data were analysed and synthesised. The overall goal was to establish what is known about the research question in the literature. The relevant information was summarised on a data withdrawal table and conclusions relevant to the research question were formulated. The evidence was synthesised in the following three steps: Extracting relevant information from included documents, Summarising the overall results from included documents and Formalising conclusions. The evidence was considered in its entirety to develop recommendations for policy and practice (Dobbins, 2017). The fifth step of the process entails identifying the applicability and transferability of aspects for further consideration during the decision-making process. This step was essential for determining how appropriate the information was to the local context (South Africa). As a result of this step, the chance of successful utilisation of 
relevant information was increased (Dobbins, 2017). The sixth and last step was to document the themes, the reliability of the proposed review was enhanced and potential personal bias regarding identification and reporting of themes was limited. The report of the executed review was submitted for examination in the article format. The review started on 05 December 2019 and ended on 28 September 2020.

\section{RESULTS/FINDINGS}

The researchers used the PRISMA (Preferred Reporting Items for Rapid Reviews and Meta-Analysis) (Liberati et al., 2009) to complete the search process. "The PRISMA flow diagram represents a standardised approach to reporting how many studies were identified for inclusion in a review, and what happened to these studies as the review progressed" (Boland et al., 2017). The findings are presented in Figure 1, below.

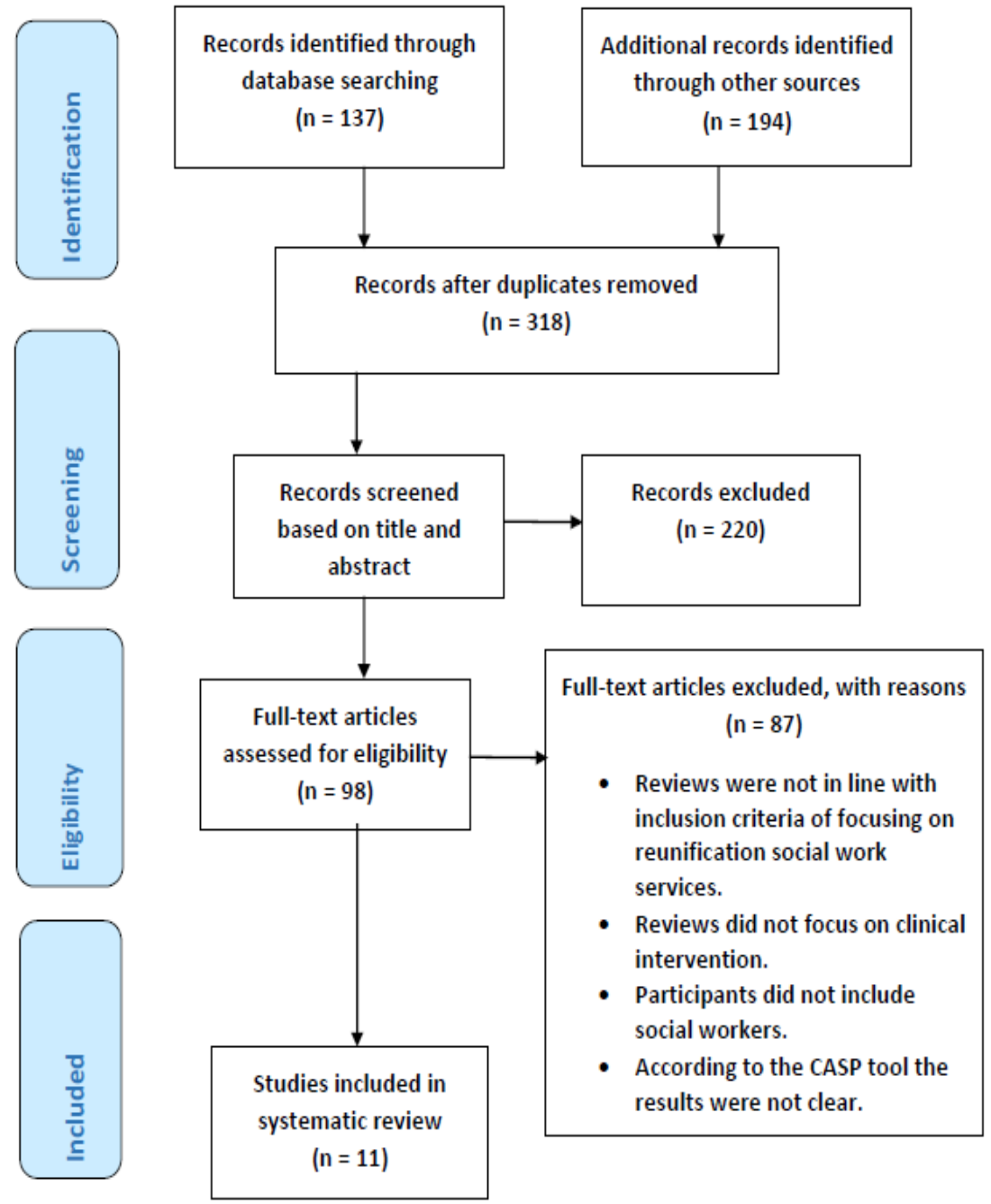

Figure 1: PRISMA 2009 Flow Diagram of selected studies

Source: Liberati et al. 2009

As illustrated in Figure 1, a total of 331 documents were found, including records identified through database searches and other sources. A total of 13 duplicate records were removed, and another 220 documents were excluded after screening the title and abstract. About 98 documents were reviewed in terms of inclusion and exclusion criteria and critically appraised. The investigated samples comprised of 11 documents that met the inclusion criteria and formed part of the rapid review, only 2 were quantitative, while 9 were evaluation designs. The quantitative studies made use of the case data analysis and electronic data capturing system (Brook et al., 2012) and (Akin \& McDonald, 2018). The evaluation designs made use of existing programmes, reports, assessment scales, literature review, informative interviews, focus group interviews, case and record analysis, meta-analysis, file review, interviews, and questionnaires (Natale et al.,2012; Orlando et al., 2019; Lewandowski \& Pierce, 2004; Enano et al., 2017; Maltais et al., 2019; Deane et al., 2018; Guerriero \& Blank, 2018; Salveron et al., 2009 and Berry et al., 2007). Table 1 provides a summary of the main findings from the included studies. 
Table 1: Summary of the main findings of included articles

\begin{tabular}{|c|c|c|c|c|}
\hline Authors & Title of article & $\begin{array}{l}\text { Method, sample } \\
\text { size, country }\end{array}$ & Main objectives & Main findings \\
\hline$\underline{\text { Brook et al. }}$ & $\begin{array}{l}\text { Analysis of the } \\
\text { impact of the } \\
\text { strengthening } \\
\text { families } \\
\text { programme } \\
\text { (SFP) on family } \\
\text { reunification in } \\
\text { child welfare. }\end{array}$ & $\begin{array}{l}\text { Quantitative } \\
\text { Design } \\
\text { Case data } \\
\text { analysis } \\
214 \text { participants } \\
\text { in the } \\
\text { strengthening } \\
\text { programme. } \\
423 \text { matched } \\
\text { non-participants. } \\
\text { Midwestern } \\
\text { State, US. }\end{array}$ & 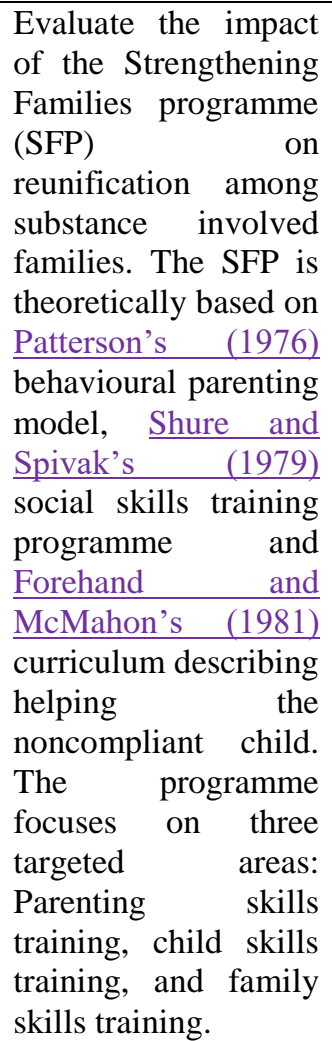 & $\begin{array}{l}\text { The findings indicated that } \\
\text { participation in the strengthening } \\
\text { families programme led to higher } \\
\text { rates of reunification, and sobriety } \\
\text { status from alcohol or other drug } \\
\text { addiction recovery was not the } \\
\text { focus of the intervention. There was } \\
\text { also improvement in parenting } \\
\text { skills, child skills, family bonding, } \\
\text { and attachment among the } \\
\text { participants. }\end{array}$ \\
\hline$\frac{\text { Natale et al. }}{(2012)}$ & $\begin{array}{l}\text { Cherish the } \\
\text { family } \\
\text { (CTF): a } \\
\text { programme } \\
\text { model of } \\
\text { strengths and } \\
\text { attachment in } \\
\text { reunifying } \\
\text { substance- } \\
\text { abusing } \\
\text { mothers with } \\
\text { their } \\
\text { children. }\end{array}$ & $\begin{array}{l}\text { Evaluation } \\
\text { design, } \\
\text { North Carolina } \\
\text { Family } \\
\text { Assessment } \\
\text { Scale- } \\
\text { Reunification } \\
\text { (NCFAS-R), } \\
\text { Parenting Stress } \\
\text { Index (PSI) and } \\
\text { Mohoney } \\
\text { Maternal } \\
\text { Behaviour } \\
\text { Rating Scales- } \\
\text { Revised (MBRS- } \\
\text { R). } \\
45 \text { intervention } \\
\text { group } \\
30 \text { comparison } \\
\text { group } \\
\text { Broward country } \\
\text { Florida, US. }\end{array}$ & $\begin{array}{l}\text { Evaluate if Cherish } \\
\text { the family (CTF), the } \\
\text { programme that uses } \\
\text { Promoting First } \\
\text { Relationships based } \\
\text { on attachment theory, } \\
\text { increases parental } \\
\text { self-sufficiency and } \\
\text { capacity to cater for } \\
\text { their child. } \\
\text { It provides court } \\
\text { support, social- } \\
\text { emotional support, } \\
\text { parenting services, } \\
\text { support groups, bus } \\
\text { passes to attendees, } \\
\text { meals, transport } \\
\text { home visits, family } \\
\text { support, substance } \\
\text { abuse treatment, } \\
\text { mental health, life } \\
\text { skills, home safety, } \\
\text { and social } \\
\text { networking. }\end{array}$ & $\begin{array}{l}\text { The findings reflect that participants } \\
\text { improved baseline/adequate or mild } \\
\text { problems in these areas to the level } \\
\text { of mild strengths. The results } \\
\text { reflected that participants are } \\
\text { enhancing their capacity to provide } \\
\text { for their children's needs and } \\
\text { improve their quality of life, which } \\
\text { is one of the programme's long- } \\
\text { term goals. } \\
\text { Cherish the family participants have } \\
\text { shown statistically significant } \\
\text { improvements in their ability to } \\
\text { understand their child's activity and } \\
\text { play interests, respond appropriately } \\
\text { to their child's behaviour, and } \\
\text { engage the child in play interaction. } \\
\text { There was also improvement in } \\
\text { other maternal domain behaviours. }\end{array}$ \\
\hline $\begin{array}{l}\text { Orlando et al. } \\
(2019)\end{array}$ & $\begin{array}{l}\text { Designing an } \\
\text { evidence-based } \\
\text { intervention for } \\
\text { parents } \\
\text { involved with } \\
\text { child welfare. }\end{array}$ & $\begin{array}{l}\text { Evaluation } \\
\text { design, } \\
\text { Literature } \\
\text { review, } \\
\text { informative } \\
\text { interviews, and } \\
\text { focus group. } \\
109 \text { participants }\end{array}$ & $\begin{array}{l}\text { Describe a three- } \\
\text { phased process to } \\
\text { develop an evidence- } \\
\text { based } \\
\text { programme (EBP) } \\
\text { with children, (birth } \\
\text { to eight years of age). } \\
\text { The study set out to } \\
\text { answer } 3 \text { research }\end{array}$ & $\begin{array}{l}\text { Five key parenting skill-based } \\
\text { domains were identified by the } \\
\text { literature review, namely: social } \\
\text { cognitive processing, impulse } \\
\text { control, parenting, social skills, and } \\
\text { stress management. } \\
\text { It was found that none of the } \\
\text { evidence-based parenting } \\
\text { programmes addresses all five }\end{array}$ \\
\hline
\end{tabular}




\begin{tabular}{ll}
\hline Washington & questions: \\
State, US. & 1) What is the need \\
& for a parenting \\
programme for & families involved \\
& with child welfare? \\
& 2) What are the gaps \\
in the current \\
evidence-based \\
parenting \\
programmes? \\
3) What content, \\
delivery method, and \\
timing are ideal for the \\
new parenting \\
intervention?
\end{tabular}

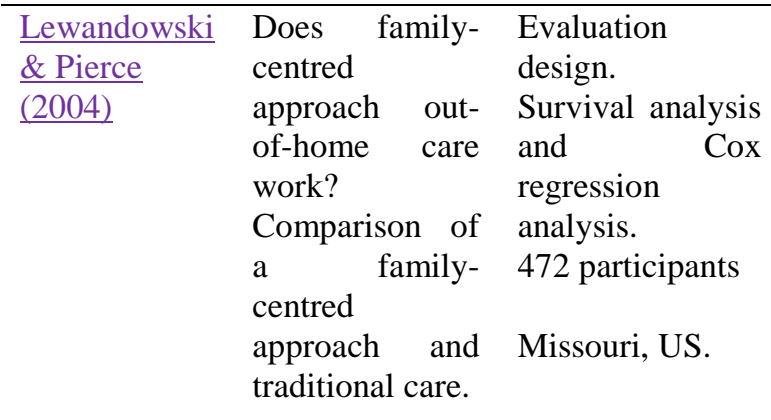

Assess Missouri’s

family-centred

approach to the outof-home care model (FCOHC) in reunifying children with their families by comparing

differential exit rates of children

Parents are referred for individual and family therapy, parenting education, drug counselling, financial assistance, help with finding housing, and job assistance.

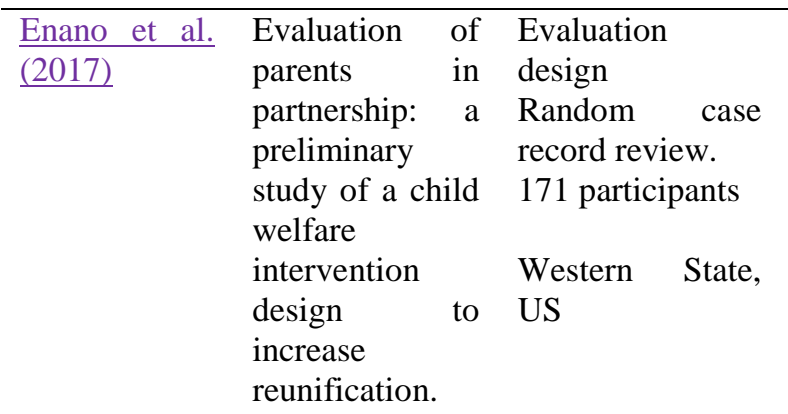

This study examines (a) if the distance was a barrier to participation in the Parent-in-partnership programme (PIP) for 98 parents

(b) if participation affected the reunification outcomes for 73 parents.

Parent-in-partnership programme services include parent orientations, parent support groups, lobby assistance, warm line support (i.e., a telephone line staffed by volunteers that oversee nonemergency questions for parents). parenting domains.

Those interviewed indicated that the current parent-child visits lacked a clear orientation to the process. Parents wanted transparency on what they were being judged on in this context.

Parent-child visitation was identified as a potential target of the intervention.
Missouri's family-centred out-ofhome care model seems to have greater success at reunifying children who are not likely to be reunified.

The findings suggest that when children are admitted to out-ofhome care for physical abuse they are more likely to return home, which suggests those families may receive adequate services.

Moreover, children are more likely to be successfully reunified with their families when workers know families better, stay in contact with children, and involve children and their families in intervention planning.

The results for the first question, compared to the control group, show that the participants were less likely to attend parent-in-partnership programme orientation if they lived further away and were more likely to attend if they were fathers and had allegations of physical or emotional abuse (compared to neglect).

Assessing distance, it appears that distance from home to the programme orientation location may be a barrier to attendance.

The results of the analyses for the second research question suggest participation in the parent orientation was related to a higher likelihood of parents reunifying with their child. Of those demographics who attended the orientation, African American mothers were more likely to reunify. Parents who attended were about five times more likely to reunify with their children than parents in the comparison group. 


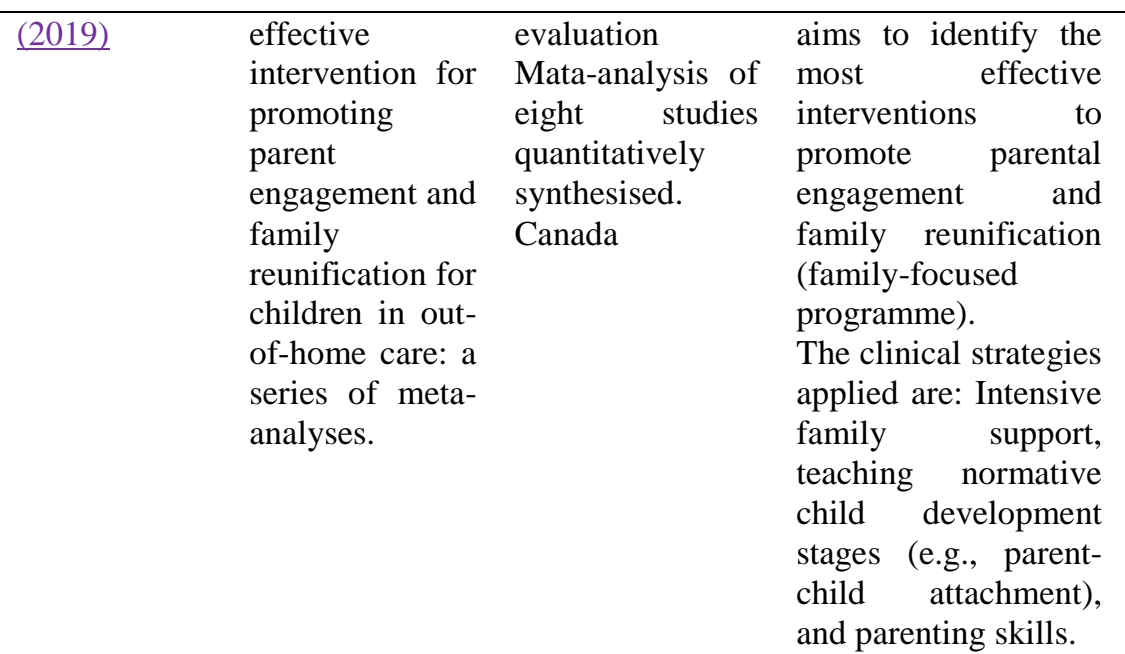

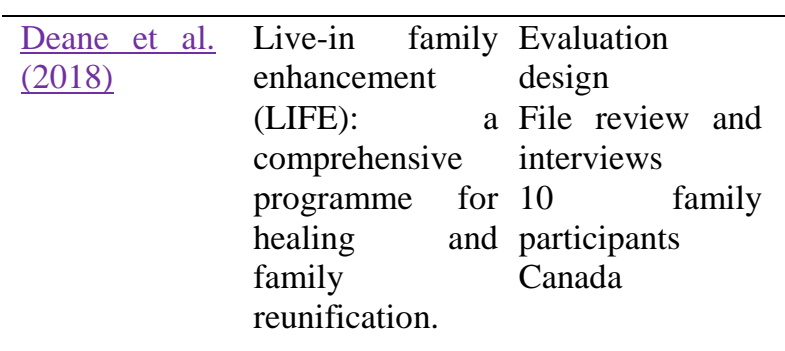

$\begin{array}{lr}\text { The } & \text { paper } \\ \text { summarises } & \text { the }\end{array}$
findings of the Livein-family enhancement (LIFE) programme.

It describes several of the outcomes of the evaluation study to answer the following questions: what impact has participation in the Live-in-family enhancement programme had on parents, children, and their entire families? How effective were the training and support provided to mentors and birth parents? Finally, this paper discusses the potential expansion of the live-in-family enhancement model beyond reunification objective and more broadly for the prevention of child maltreatment. engagement interventions with a family-focused modality were more effective in promoting parental engagement than interventions that did not make use of a family modality and only provided standard services.

In comparison to their standard services counterparts, goal-oriented interventions were more likely to increase family reunification, with children nearly 2.5 times more likely to be reunited with their families.

The study reveals that individualised treatments, overall, are not as effective as those which include a family dimension. These results favour a family-focused and support previous research showing that parent-child or family-based interventions generally yield more positive outcomes in terms of parents and their children, in comparison to standard interventions. This can be observed in higher levels of parental sensitivity and child attachment security, or low level of child behaviour problems.

The evaluation of the programme suggests that for most parents the outcomes in these areas were positive or promising. Much of this seemed to be made possible through the trust relationships that were built by a sustained day-to-day interaction over a significant period. The findings show a significant number of benefits to families such as stronger attachment between parents and children, improved parenting skills for caregivers, strengthened social support for families, newly acquired household management skills, successful completion of employment training, and significantly improved level of trust in social workers and the agency. Many of these factors correlate with research supporting increased rates of family reunification. 


\begin{tabular}{|c|c|c|c|c|}
\hline & & & $\begin{array}{l}\text { The client families } \\
\text { received coaching } \\
\text { and support in terms } \\
\text { of parenting on a } \\
\text { moment-to-moment } \\
\text { basis, seven days per } \\
\text { week, and had access } \\
\text { to a full range of } \\
\text { other supports such } \\
\text { as attachment-based } \\
\text { parenting training, } \\
\text { anger management } \\
\text { training, substance } \\
\text { abuse relapse } \\
\text { prevention, } \\
\text { employment } \\
\text { assistance, assistance } \\
\text { with nutrition and } \\
\text { budgeting, support } \\
\text { with issues at school } \\
\text { or day-care, and a } \\
\text { range of other } \\
\text { resources needed to } \\
\text { become competent } \\
\text { and nurturing } \\
\text { families. }\end{array}$ & \\
\hline$\frac{\text { Guerriero \& }}{\underline{\text { Blank }}}$ & $\begin{array}{l}\text { Music therapy in } \\
\text { a parent-child } \\
\text { reunification } \\
\text { programme: } \\
\text { Benefits and } \\
\text { challenges of } \\
\text { implementation }\end{array}$ & $\begin{array}{l}\text { Evaluation } \\
\text { design } \\
\text { United States }\end{array}$ & $\begin{array}{l}\text { The Reunite House } \\
\text { Programme and } \\
\text { Music Together } \\
\text { approach teaches } \\
\text { personal and } \\
\text { responsibility s a } \\
\text { parenting skills in a } \\
\text { respectful, nurturing, } \\
\text { home-like to } \\
\text { environment child abuse } \\
\text { reduce child } \\
\text { and neglect, decrease } \\
\text { the time children } \\
\text { spend in foster care, } \\
\text { and strengthen } \\
\text { families throughout } \\
\text { communities. } \\
\text { This article describes } \\
\text { two different } \\
\text { implementations of a } \\
\text { music therapy group } \\
\text { within a reunification } \\
\text { programme, the } \\
\text { clinical and } \\
\text { contextual challenges } \\
\text { to implementation, } \\
\text { and the benefits to } \\
\text { the families. }\end{array}$ & $\begin{array}{l}\text { Music therapy was a vital } \\
\text { component of the reunification } \\
\text { process for families who had been } \\
\text { legally separated due to abuse or } \\
\text { neglect. } \\
\text { The music therapy groups allowed } \\
\text { parents to bond with their children } \\
\text { during parental visits through a } \\
\text { family participation model, parent } \\
\text { education, and developmentally } \\
\text { appropriate approaches to music- } \\
\text { making. } \\
\text { Parents could become comfortable } \\
\text { making music with their children } \\
\text { through means of the predictable } \\
\text { structure of this group. Positive } \\
\text { signs of increased parent-child } \\
\text { bonding included parents sitting } \\
\text { comfortably with their children and } \\
\text { other families in a circle, and } \\
\text { increased use of instruments and } \\
\text { movement props. } \\
\text { Parents are also provided additional } \\
\text { information through informal } \\
\text { interactions with the music therapist } \\
\text { and social workers on how to use } \\
\text { music outside the music therapy } \\
\text { session. }\end{array}$ \\
\hline $\begin{array}{ll}\text { Salveron et } & \text { et }(2009) \\
\text { al. }\end{array}$ & $\begin{array}{l}\text { Parenting } \\
\text { groups for } \\
\text { parents whose } \\
\text { children are in } \\
\text { care. }\end{array}$ & $\begin{array}{l}\text { Evaluation } \\
\text { design } \\
\text { Focus group } \\
\text { interviews } \\
17 \text { parent } \\
\text { participants } \\
15 \text { staff } \\
\text { participants } \\
\text { Australia }\end{array}$ & $\begin{array}{l}\text { The objective was to } \\
\text { review the Parent } \\
\text { Plus Playgroups, a } \\
\text { group-based } \\
\text { approach when } \\
\text { working with birth } \\
\text { parents whose pre- } \\
\text { school-aged children } \\
\text { had been placed in }\end{array}$ & $\begin{array}{l}\text { Findings from the research project } \\
\text { indicate that the parents plus } \\
\text { playgroups were well-liked by } \\
\text { parents and are a promising way to } \\
\text { engage parents whose children are } \\
\text { being looked after. } \\
\text { Parents plus playgroups } \\
\text { demonstrated an elevated level of } \\
\text { parental and familial involvement in }\end{array}$ \\
\hline
\end{tabular}


care. The paper reports the findings of a research project designed to identify key facilitators and barriers to parental involvement in a group-based programme, which includes contact between parents and their children.

If programmes such as parents plus can have a positive impact on factors such as parental shame and parenting satisfaction, this may in turn provide an environment conducive attitudinal,

attributional, and behavioural change that can improve the quality of parentchild relationships and the chances of family reunification. the planning and implementation of the programme. It also demonstrates improved parental parenting satisfaction and decreases in parental shame over the two months of the project.

There were no significant changes in parental efficacy, social support, pride, or guilt; this may be due to the limited sample size, the short follow-up period, and/or because parents had already been involved with the programme.

\begin{tabular}{|c|c|c|c|c|}
\hline$\frac{\text { Berry et al. }}{(2007)}$ & $\begin{array}{l}\text { Permanency } \\
\text { through group } \\
\text { work: A pilot } \\
\text { intensive } \\
\text { reunification } \\
\text { programme. }\end{array}$ & $\begin{array}{l}\text { Evaluation } \\
\text { design } \\
\text { Questionnaires, } \\
\text { inventories, and } \\
\text { forms into the } \\
\text { usual } \\
\text { information } \\
\text { assessed and } \\
\text { recorded by staff. } \\
\text { The Lutheran } \\
\text { social services } \\
\text { screening tool, } \\
\text { Adult Adolescent } \\
\text { Parenting } \\
\text { Inventory, } \\
\text { Strengths, and } \\
\text { stressors tracking } \\
\text { device and } \\
\text { Interviews with } \\
\text { social workers, } \\
\text { family support } \\
\text { workers, and } \\
\text { families. } \\
\text { 12 participants in } \\
\text { the programme }\end{array}$ & 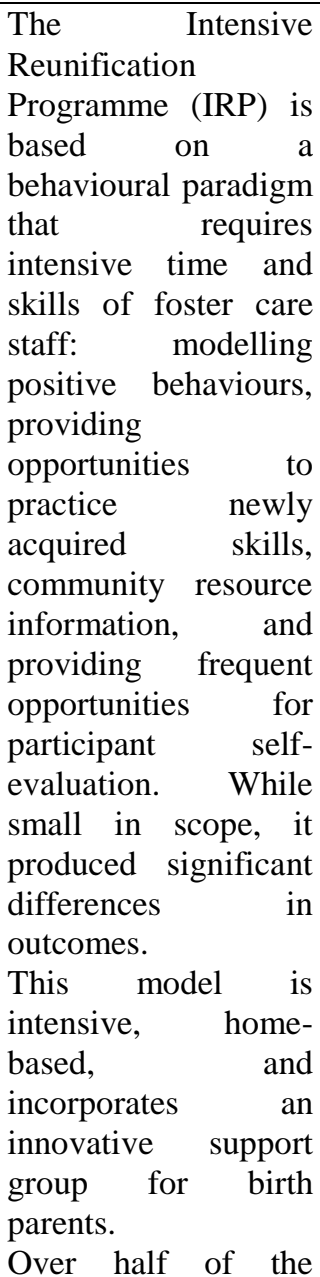 & $\begin{array}{l}\text { The programme has had greater } \\
\text { success with families referred for } \\
\text { neglect than for abuse, which is } \\
\text { unusual. Neglect cases typically } \\
\text { have much slower times to } \\
\text { reunification and much lower rates } \\
\text { of reunification. } \\
\text { Using the adult adolescent parenting } \\
\text { inventory at intake and nine months } \\
\text { later, the greatest gains made by } \\
\text { parents while in the programme } \\
\text { were in the areas of accepting the } \\
\text { child's power and independence, } \\
\text { and parental expectations of the } \\
\text { child. } \\
\text { Changes in parental empathy, } \\
\text { beliefs in corporal punishment and } \\
\text { family roles were small. } \\
\text { To best empower parents, and make } \\
\text { the group experience as relevant as } \\
\text { possible, parent group participants } \\
\text { are asked to identify the kind of } \\
\text { information and educational topics } \\
\text { they would like to discuss in some } \\
\text { sessions. Staff guide parents to base } \\
\text { their choices on addressing those } \\
\text { issues responsible for the removal of } \\
\text { their children. } \\
\text { A comparative evaluation of this } \\
\text { model after one year finds that its } \\
\text { reunification rates are double that of } \\
\text { cases receiving the agency's }\end{array}$ \\
\hline
\end{tabular}




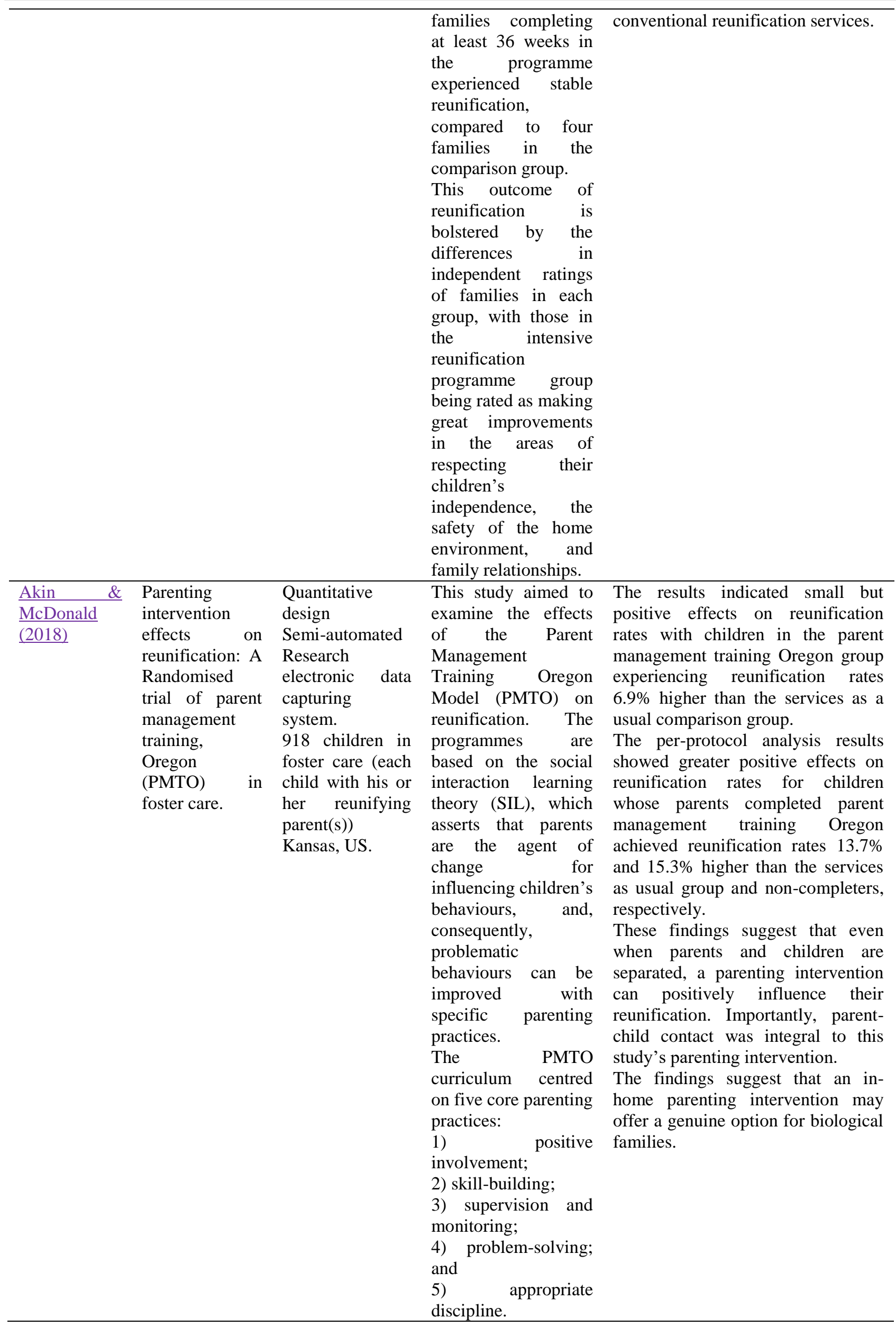




\section{DISCUSSION}

The removal of the children from their biological parent's care and placement in alternative care due to unfortunate circumstances remains an expected phenomenon in the child protection sector. While the fundamental goal of alternative care is decisive and much needed in the sense of providing safer living circumstances for children in need of care and protection, family reunification intervention services are highly recommended immediately after the child has been placed in alternative care within the child protection system. Designated social workers are expected to begin work with the birth parents as soon as possible since, without this intervention, it is very difficult, or unlikely, that the cause of separation will be resolved and that the child will be able to return home (Balsells et al., 2014). This process is driven by the aim to re-establish healthy interaction between birth parents and the child, develop attachment and repair the emotional anxiety in both the child and birth parents to make up for the lost time while they were separated (Rasaili \& Titus, 2007).

The data from the rapid review has highlighted different clinical intervention programme contents, which are proven, recommended, and more likely to increase the success of reunification services to children and families. The analysis was conducted according to the six-phase guide suggested by Braun and Clarke (2006), and four central themes were identified and are discussed:

\section{Theme one: Engagement}

To promote effective changes in birth parents and ensure the success of the family reunification process, birth parents have to be actively engaged in terms of the services (Maltais et al., 2019). The results of a meta-analysis study conducted by (Maltais et al., 2019) indicate that goal-oriented engagement interventions with a family-focused approach in comparison to other goal-oriented interventions not including family-focused services or standard services were more effective in promoting parental engagement. Programmes focus on three targeted areas: Parenting skills training, child skills training, and family skills training. The content is focused on child development, behaviour management techniques, child skills training, family enhancement and attachment/bonding, parental supervision, and psychoeducational material targeted at improving the parent-child relationship. Parent-child activities or family-focused intervention were found or identified to be more successful in promoting family reunification, as opposed to individual psychotherapy (Maltais et al., 2019). Family programmes increase parental self-sufficiency and enhance the parents' capacity to cater to their child, children's needs and improve their quality of life.

\section{Theme two: Parental visits and contact}

The findings identify that early parent-child visits are a critical and untapped opportunity for parenting intervention. Moreover, parent-child visits may be powerful in that early support and education can enhance parental engagement in the visitation process and potentially affect engagement in other needed services (Orlando et al., 2019). Ideally, visits should start within the first few weeks of placement. Early support around visits is needed. Often, parents are unaware of what is expected of them in their visits and feel judged. Furthermore, visits that do not go well traumatise both parents and children. The sessions of visitation programmes should focus on the following (a) one-on-one instructional session with the birth parents an hour before a parent-child visit; (b) a supported parent-child visit (try out new knowledge and skill); and (c) 15 minutes debrief session with the parent following the visit without the children present. In these sessions' skill-building is an important aspect that should not be ignored. Parents need to learn and apply practical, developmentally appropriate, and effective parenting techniques. The one-on-one approach works best for skill and relationship building, groups are better at providing support. Trauma-informed programmes must be included in the family reunification intervention programmes. This is because at times trauma, as a result of children being removed from the care of their parents, is common and often goes unaddressed by existing reunification programmes.

\section{Theme three: Parenting capacity building}

Parent training is, in part, aimed at preventing the onset or recurrence of child maltreatment by teaching parents muchneeded skills and improving their functioning in areas that have been shown to increase the risk of child neglect or abuse. Some parent-training programmes also include interventions aimed at increasing children's skills and overall family functioning, rather than focusing solely on the parents (Brook et al., 2012). The content includes child development, behaviour management techniques, family enhancement and bonding, parental supervision, as well as psycho-educational material aimed to improve parent-child relations. The focus is not only on the parent behaviour but also includes child behaviours and overall family functioning in families characterized by substance abuse. The strengthening family programme was designed specifically for substance-abusing families with the primary prevention of child maltreatment as a focus (Brook et al., 2012).

\section{Theme four: Support groups}

The findings of this study also highlighted support group programmes to be vital in family reunification. The parent-inpartnership programme is a parent mentorship programme. The programme involves a group of birth parents that have successfully navigated the system. The birth parents work in partnership with the child welfare system and provide information to current programme participants, empowerment, and hope. They also provide support, information, and mentorship to birth parents who have recently lost custody of their children, as well as parents whose children are in foster care temporarily (Enano et al., 2017). 
Evidence from this rapid review suggests that removal of a child from direct risk of maltreatment alone has little influence in changing the circumstances of a home, improving a parent's disciplinary style, or their anger management skills; nor does it encourage more responsive parenting. Thus, family reunification intervention is necessary to strengthen, and support affected families so that they can provide a more suitable environment for their child's development and obtain skills to learn responsive parenting.

This study highlighted engagement, parental visit and contact, parenting capacity building, and support groups as forming a crucial part of the clinical reunification intervention to ensure safe and timely reunification. Clinical interventions must focus on engaging families in the assessment and case planning, encouraging and supervising parentchild contact, and equip birth parents with much-needed skills through evidence-based parenting skills programmes. Such programmes aim to link families with networks of support in their communities. Clinically natured intervention engages clients directly, intensely, and broadly to enable necessary changes in individual behaviour or relationships.

Concrete services were identified as additional material assistance needed for the families, such as food, transport money and clothing. In an attempt to render successful family reunification intervention, it is crucial to consider the wider family context, which includes financial and housing circumstances, characteristics of individual family members, like a child's behavioural and health problems, and parents' abilities.

\section{CONCLUSION}

The information that was gleaned from the study provided an understanding of what the clinical content of reunification intervention services is and its importance since they are aimed at directly improving the emotional, psychological, and personal functioning of both the birth parent and child, rather than providing for tangible needs. The literature consistently shows that families with multi-stressors require well-strategized, family-centred interventions that are more focused on decision-making, planning, and the provision of services directed to the needs of birth parents and children (both pre-and post-family reunification). Moreover, these must be provided in the context of skilled and purposeful relationship-based social work, where the needs and vulnerabilities of each child are comprehensively assessed, together with the birth parents' ability to change (Farmer, 2018). The application of a family-centred approach during reunification improves a worker's contact with clients, and their provision of concrete services, mental health interventions, drug and alcohol services, and skill development opportunities.

\section{LIMITATION AND STUDY FORWARD}

Despite the initial rigorous searches, the researcher found limited data sources that are specifically focused on the clinical content of reunification intervention for families. Only 11 data sources met the inclusion criteria of the study, of which 3 were grey literature. Only full-text data sources available through the NWU's One Search engine portal were included and only those in English and Afrikaans were considered. This can be considered as a limitation. The researchers acknowledge that the review had a specific focus, which meant that there was a scope limitation only, about the clinical content of reunification intervention rendered to families. As a result of this, some articles may have been excluded. Another factor that contributed to the exclusion of some articles was that most of the studies were more focused on reunification outside social work practice and child protection; the reunification of refugees with their significant others is a good example of this. Only11 of the initial three 331 articles were included. The rest of the articles were excluded because they were outdated and, therefore, did not meet the requirements of the search.

\section{ACKNOWLEDGEMENT}

The authors acknowledge the North-West University’s Community Psychosocial Research (COMPRES) entity, South Africa, for their support in writing this scientific journal.

\section{REFERENCES}

1. Akin, B. A., \& McDonald, T. P. (2018). Parenting intervention effects on reunification: A randomised trial of PMTO in foster care. Child Abuse and Neglect, 83(4), 94-105. https://doi.org/10.1016/j.chiabu.2018.07.011

2. ASPE Research Brief. (2016). Patterns of foster care placement and family reunification following child maltreatment investigations. $\quad$ https://aspe.hhs.gov/pdf-report/patterns-foster-care-placement-and-familyreunification-following-child-maltreatment-investigations

3. Balsells, M. A., Paster, C., Mateos, A., Amorós, P., Ponce, C., \& Navajas, A. (2014). Child welfare and successful reunification through the socio-educative process: Training needs among biological families in Spain. Social Science Journal, 3(4), 809-826. https://doi.org/10.3390/socsci3040809

4. Berk, L. E. (2009). Child development (8th ed). Pearson

5. Berrick, J. D. (2008). Take me home: Protecting America's vulnerable children and families (1st ed.). Oxford University Press.

6. Berry, M., McCauley, K., \& Lansing, T. (2007). Permanency through group work: A pilot intensive reunification program. Child Adolescent Social Work Journal, 24(5), 47-493.

7. Boland, A., Cherry, M. G., \& Dickson, R. (2017). Doing a systematic review: A student's guide (2nd ed.). Sage.

8. Braun, V., \& Clarke, V. (2006). Using thematic analysis in psychology. Qualitative Research in Psychology, 3(2), 77-101. https://doi.org/10.1191/1478088706qp063o 
9. Bromfield, L. M., Lamont, A., Parker, R., \& Horsfall, B. (2010). Issues for the safety and wellbeing of children in families with multiple and complex problems. National Child Protection Issues, 33, 1-23.

10. Bronson, D. E., Saunders, S., Holt, M. B. \& Beck, E. (2008). Systematic review of strategies to promote successful reunification and to reduce re-entry to care for abused, neglected, and unruly children. Paper delivered at the Ohio Department of Job and Family Service, Ohio. http://www.ocwtp.net/PDFs/ReunReentry\%20Final\%20Report.pdf

11. Brook, J., McDonald, T. P., \& Yan, Y. (2012). Analysis of the impact of the strengthening program of family reunification in child welfare. Child and Youth Services Review, 34(4), 691-695. https://doi.org/10.1016/j.childyouth.2011.12.018

12. Canadian Centre on Substance Use and Addiction. (2014). CCSA Rapid Review Methodology. https://ccsa.ca/ccsa-rapid-review-methodology

13. Corey, G. (2013). Theory and practice of counselling and psychotherapy. (9th ed.). Brooks Cole.

14. Critical Appraisal Skills Programme. (2018). CASP checklist. https://casp-uk.net/wpcontent/uploads/2018/03/CASP-Qualitative-Checklist-2018_fillable_form.pdf

15. Child Welfare Information Gateway. (2011). Family reunification: what the evidence shows. https://www.childwelfare.gov/pubs/issue briefs/family_reunification/index.cfm

16. Child Welfare Information Gateway. (2017). Supporting successful reunifications. https://www.childweldare.gov/pubPDFs/supportingreunication.pdf

17. Deane, L., Glass, J., Spence, I. V., \& Mignone, J. (2018). Live-in family enhancement (LIFE): A comprehensive program for healing and family reunification. First People Child and Family Review, 13(1), 3549.

18. Department of Social Development (South Africa). (2013). White paper on families. https://www.westerncape.gov.za/assets/departments/socialdevelopment/white_paper_on_families_in_south_afri ca_2013.pdf

19. De Villiers, A. (2008). The role of the social worker in the reunification of foster children with their birth parents. (Unpublished master's dissertation). University of Stellenbosch, Stellenbosch.

20. Dobbins, M. (2017). Rapid review guidebook: Steps for conducting a rapid review. https://www.nccmt.ca/uploads/media/media/0001/01/a816af720e4d587e13da6bb307df8c9 07a5dff9a.pdf

21. Dundar, Y., \& Fleeman, N. (2014). Developing my search strategy and applying inclusion criteria. In: A. Boland., M. G., Cherry., \& R. Dickson (Eds.), Doing a systematic review: A student's guide (2nd ed., pp. $37-$ 59). Sage.

22. Enano, S., Freisthler, B., Johnson, D. P., \& Hermann, K. L. (2017). Evaluation parents in partnership: A preliminary study of a child welfare intervention design to increase reunification. Journal of Social Services Research, 43(2), 236-245. https://doi.org/10.1080/01488376.2016.1253634

23. Effective Public Health Practice Project. (2009). Quality assessment tool for quantitative studies. http://www.ephpp.ca/tools.html

24. Farmer, E. 2018. 'Reunification from out-of-home care: A research overview of good practice in returning children home from care'. http://www.bristol.ac.uk/sps/research/projects/completed/2016/ returninghome/

25. Fernandez, E., \& Lee, J. (2013). Accomplishing family reunification for children in care: Australian study. Children and Youth Services Review, 35(9), 1374-1384. https://doi.org/10.1016/j.childyouth.2013.05.006

26. Forehand, R., \& McMahon, R. J. (1981). Helping the noncompliant child: A clinician's guide to parent training. New York: Guilford Press.

27. Government of Western Australia. (2011). The signs of safety child protection practice framework. https://www.dcp.wa.gov.au/Resources/Documents/Policies\%20and\%20Frameworks/SignsOfSafetyFramework 2011.pdf

28. Gray, M. \& Lombard, A. (2008). The post-1994 transformation of social work in South Africa. The International Journal of Social Welfare, 17(2), 132-145. https://doi.org/10.1111/j.1468-2397.2007.00545.x

29. Guerriero, A., \& Blank, C. A. (2018). Music therapy in parent-child reunification program: Benefits and challenges of implementation. Voices, 18(4), Article 2601. https://doi.org/10.15845/voices.v18i4.2601

30. Harker, J. \& Kleijnen, J. (2012). What is a rapid review? A methodological exploration of rapid reviews in health technology assessments. International Journal of Evidence-Based Healthcare, 10(3), 397-410. https://www.readcube.com/articles/10.1111\%2Fj.1744-1609.2012.00290.x

31. Hepworth, D. H., Rooney, R. H., Rooney, G. D., Strom-Gottfried, K., \& Larsen, J. (2013). Direct social work practice. Theory and skills (9th ed.). Thomson Brooks/Cole.

32. Holland, S. (2011). Child and family assessment in social worker practice (2nd ed.). Sage.

33. Kunz, J. (2013). Think marriages and families. (2nd ed.) Pearson.

34. Lewandowski, C.A., \& Pierce, L. (2004). Does family-centered out-of-home care work? Comparison of a family-centered approach and traditional care. Social Work Faculty Publications, 28(3), $143-151$. https://doi.org/10.1093/swr/28.3.143

35. Liberati, A., Altman, D. G., Tetzlaff, J., Mulrow, C., Gøtzsche, P. C., Ioannidis, J. P. A., Clarke, M., Devereaux, P. J., Kleijnen, J., \& Mohe, D. (2009). The PRISMA statement for reporting systematic reviews and meta-analyses of studies that evaluate healthcare interventions: explanation and elaboration. https://www.bmj.com/content/bmj/339/bmj.b2700.full.pdf 
36. Lietz, C. A. \& Strength, M. (2011). Stories of successful reunification: A narrative study of family resilience in child welfare. Families in Society: The Journal of Contemporary Social Services, 92(2), 203-210. https://.doi.org/10.1606/1044-3894.4102

37. Maltais, M., Cyr, C., Parent, G., \& Pascuzzo, K. (2019). Identifying effective intervention for promoting parent engagement and family reunification for children in out-of-home care: A series of Meta-analysis. Child Abuse and Neglect, 88, 262-375. https://doi.org/10.1016/j.chiabu.2018.12.009

38. Murphy, E., \& Fairtlough, A. (2014). The successful reunification of abused and neglected looked after children with their families: A case file audit. British Journal of Social Work, 45(8), 2261-2280. https://doi.org/10.1093/bjsw/bcu093

39. Natale, R., Scott, S. H., Camejo, S. T., Harnandez, M., \& Sellas-Lamberty, O. S. (2012). Cherish the family: A program model of strengths and attachment in reunifying substance-abusing mothers with their children. Child Welfare Journal, 91(5), 73-95.

40. Nicklin, J. A. (2019). Case managers' perspectives on how to achieve timely reunification (unpublished master's dissertation). Retrieved from https://doi.org/10.26182/5db28c68be3d8

41. Orlando, L., Barkan, S., \& Brennan, K. (2019). Designing an evidence-based intervention for parents involved with child welfare. Children and Youth Services Review, 105. https://doi.org/10.1016/j.ch ildyouth.2019.104429

42. Patterson, G. R. (1976). Living with children: New methods for parents and teachers. Rev. ed. Champaign, IL: Research Press.

43. Pecora, P. J. \& Maluccio, A. N. (2000). What works in family foster care. In: Kluger, M.P., Alexander, G. \& Curtis, P. A. (Eds.), What works in child welfare (pp. 139-155). Child Welfare League of America. https://doi.org/10.1093/acprof:oso/9780195175912.001.0001

44. Rasaili, T. R., \& Titus, C. M. (2007). Reunification: A reality or an impossible dream. (unpublished master'sdissertation). https://gupea.ub.gu.se/bitstream/2077/4609/1/Complete\%20final\%20thesis\%2 02.pdf

45. Ryan, J. P., \& Schuerman, J. R. (2004). Matching family problems with specific family preservation services: A study of service effectiveness. Children and Youth Services Review, 26(4), 347-372. https://doi.org/10.1016/j.childyouth.2004.01.004

46. Salveron, M., Lewig, K., \& Arney, F. (2009). Parenting groups for parents whose children are in care. Child Abuse Review, 18(4), 267-288. https://doi.org/10.1002/car.1070

47. Shure, M. B., \& Spivak, G. (1979). Interpersonal cognitive problem solving and primary prevention: Programming for preschool and kindergarten children. Journal of Clinical Child Psychology, 8, 89-94.

48. Siriwardhana, C., Ali, S. S., Roberts, B., \& Stewart, R. (2014). A systematic review of resilience and mental health outcomes of conflict-driven adult forced migrants. Conflict and Health, 8(1), art.\#13. https://doi.org/10.1186/1752-1505-8-13

49. South Africa. (2005). Children's Act 38 of 2005. Pretoria: Government Printers.

50. Tyndall, J. (2010). The AACODS checklist is designed to enable evaluation and critical appraisal of grey literature.https://dspace.flinders.edu.au/xmlui/bitstream/handle/2328/3326/AACODS_Checklist.pdf?seq uence $=4$ \&isAllowed $=y$

51. United Nations. (2010). Guideline for the alternative care of children. https://www.unicef.org/protecti on/alternative care Guidelines-English.pdf-

52. Westfalls Associates. (2014). Theories of motivation. http://www.westfallsassociates.com.au 